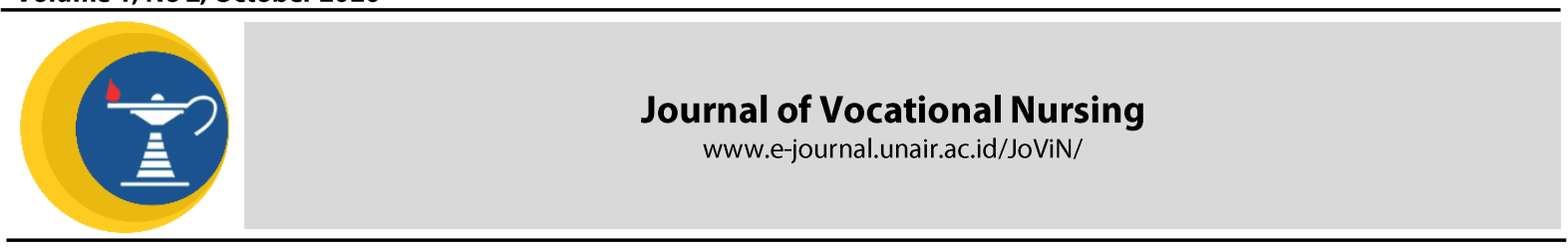

\title{
IDENTIFICATION OF KNOWLEDGE OF BULLYING IN ADOLESCENTS AND ITS EFFECTS ON BEHAVIOR OF BULLYING FRIENDS
}

\author{
Abd. Nasir ${ }^{1}$, Rindayati ${ }^{2}$,Iswatun ${ }^{3}$,Anestasia Pangestu Mei Tyas ${ }^{4}$ and Bela Dwi Kurnia \\ Putri $^{5}$ \\ $1.2,3,4,5$ DIII Nursing Study Program, Departement of Health, Faculty of Vocational Studies, Universitas Airlangga
}

Research Report

ARTICLE INFO

\section{ABSTRACT}

Introduction: Bullying behavior committed by fellow students at school is always associated with the search for self-identity and social status, but the behavior is very disturbing and has caused many victims. This study is to analyze the relationship of knowledge about bullying in adolescents and its influence on bullying behavior among peers. Methods: Data for this exploratory study were collected using a cross-sectional model. The study sample consisted of 80 students at SMAN 1 Kebomas Gresik who met the inclusion criteria. The independent variable is bullying knowledge. The dependent variable is bullying behavior. Two questionnaires were used in this study, knowledge about bullying and bullying behavior. The statistical test used is the Spearman Rank test with a significance level of $a=0.05$. Results: the average sex of the respondent was 1.38 (SD: 0.487), the average age of the respondent was 1.90 (SD:0.739), the average socioeconomic respondent was 2.75 (SD: 0.490), the average occupation of the respondent was 2.05 (SD: 0.525), the average bullying behavior of respondents is 1.40 (SD: 0.668), and there is a positive-negative relationship between knowledge and bullying behavior in adolescents $(p=0,000)$. Conclusion: increased knowledge about bullying can reduce bullying behavior. This is necessary for health education to improve understanding of the terror behaviors that are usually carried out by adolescents as a result of the moral release response from the growth and development process that is always experienced by adolescents so that they leave the knowledge possessed.

\author{
Recived 16 October 2020 \\ Accepted 27 October 2020 \\ Online 29 October 2020 \\ *Correspondence: \\ Abdul Nasir \\ *Email: \\ abdoel.nasir@gmail.com
}

\section{INTRODUCTION}

Bullying behavior in schools has been very disturbing and has caused many victims. Annual Review results are published by around 20$25 \%$ of adolescents who have been opponents and victims of bullying, 4-9\% often commit bullying, and school children have been terrorized around 9-25\% (Juvonen and Graham, 2014). The Global Status Report on School Violence and Bullying regarding bullying victims in several countries, and found that students who were victims reached a range of $22.8 \%$ to $48.2 \%$, obtained through physical contact or study (25.6\% - 46.3\%) and physical attacks (20.5\% - 38\%) (UNESCO, 2019). The results also prove that $26 \%$ of students have successfully overcome bullying, $33 \%$ with physical violence, and older adolescents of their peers are often subject to terror (Al
Buhairan et al., 2017), and the current trend of using cyberbullying (Young, Miles and Alhabash, 2018). Men are more often perpetrators of bullying (Itegi, 2017), and women with psychological problems who are victims but are at risk for men (Le et al., 2019), so students involved in bullying are related to psychiatric problems (Sigurdson et al., 2015).

Permissive attitudes toward violent behavior by students, families, schools, and communities contribute to bullying behavior (Lopes Neto, 2005), and the initial purpose of bullying behavior by students, is associated with the search for self-identity and social status (Bjorklund and Pellegrini, 2002; Bellmore et al., 2017), so that it is considered not a problem even though victims of bullying feel terrorized because of bullying (Craig, Pepler, and Atlas, 2000). But the 
way the bullying is done, unintentionally shows behavior that is less assertive and tends to attack. Some bullying behavior that often done is impolite (Stein, Dukes, and Warren, 2007), to antisocial (Barzeva, Meeus and Oldehinkel, 2019), and followed by sexual harassment (Oriol, Miranda, and Amutio, 2019), giving rise to physical and psychological problems (Baldry, 2004), insecurity (Serra-Negra et al., 2015; Waisglass, 2017; Oriol, Miranda and Amutio, 2019), and reduce the quality of life of students (Diaz Herraiz and Gutierrez, 2017).

Other studies have found the contribution of bullying through physical contact and the mass media or cyberbullying associated with drug abuse, irritability, and anger, sexual deviations, (Litwiller and Brausch, 2013) (Rivers et al., 2009). If deemed very painful, not infrequently victims of bullying commit suicide (Fujikawa et al., 2016; Hinduja and Patchin, 2019) so that recovery takes a long time (Baldry, 2004; Fisher, Cassidy and Mitchell, 2017). Bullying behavior is an attempt to attack someone physically, verbally and socially aggressively, repeatedly carried out until the victim is helpless (Menesini and Salmivalli, 2017). Forms of physical attacks include hitting, kicking, damaging the victim's property, verbal attacks (mentioning inappropriate names or threatening), and social aggression (exclusion or fake news) (Smith, 2014).

However, most students have not been able to recognize bullying behavior. The teacher only tells about what to do to stop bullying at school but not to identify and differentiate it (Bellmore et al., 2017). Except for physical intimidation (Aulia, 2016), verbal bullying and social aggression are still not considered forms of intimidation, because they can be felt (Nasheeda, Hassan and Hassan, 2016). Parents and teachers are the parties responsible for understanding bullying behavior in children or students (Lopes Neto, 2005) because there is a lot of evidence that can be used as a basis for bullying in schools when clarifying the reasons related to student academic achievement (Van Werf, 2014; Al-Raqqad et al., 2017; Oliveira et al., 2018), dropout events (Townsend et al., 2008; Beilmann, 2017), and psychosocial problems experienced by some students at school (Rivers et al., 2009; Darney, Howcroft, and Stroud, 2013; Fanti and Henrich, 2015; Fullchange and Furlong, 2016). For this reason, research on knowledge and bullying has not been done much, so it is very interesting to be investigated.

Adolescent development that wants to show self-identity and social status needs to be maintained by an educator by directing positive activities. Errors in showing self-realization result in deviant behavior and tend to commit violence against fellow friends which will damage friendships. The aim of our study was to identify knowledge and its effects on peer bullying behavior in adolescents. What is the relationship of knowledge in adolescents and bullying behavior with fellow friends.

\section{MATERIALS AND METHODS}

Data for this observational analytic study was collected using a cross-sectional, nonexperimental design. The study population consisted of class $X$ students at SMAN 1 Kebomas Gresik recorded in the 2018-2019 school year (a total of 80 students). The sample of this study was determined based on the following inclusion criteria: 1) adolescents of the school in SMA N 1 Kebomas, (2) adolescents who were registered as students of grade $X$ in SMAN 1 Kebomas as evidenced by Student Cards, (3) adolescents chose the Social Sciences major. The independent variable in this research is knowledge about bullying. The dependent variable in this study is peer bullying behavior. After granting approval, this research was conducted at SMAN 1 Kebomas, Gresik Regency.

Data collection starts from June to July 2019. Initial data collection was completed by selecting candidates according to inclusion criteria. The subjects in this study were students of class X SMAN 1 Kebomas Gresik. The total number of class $X$ students at SMAN 1 Kebomas Gresik is 190 students spread into 6 classes, and students majoring in Social Sciences are 80 students / students. The questionnaire used was bullying behavior. It is used to determine adolescent behavior to peers. The validity test results obtained 30 valid items with a reliability value of $r=0.8436$. The questionnaire consists of questions about youth bullying behavior, which can choose from the following responses: "0: never; 1: sometimes; 2 : often; and 3: very often". Bullying behavior in adolescents is determined by the following scores: usually done: 0 - 50 and not normally done 51-100. In the first step, a descriptive statistical analysis which includes frequency, mean and standard deviation, was realized in all samples including gender, age, parity, place of residence. The next step Sperman Rhank is used to analyze the relationship between knowledge about bullying and bullying behavior with a significance level of significance $a=0.05$. Statistical analysis was performed using IBM SPSS statistical software, version 20.0. The author states that this research has no conflict of interest, and is conducted in accordance with ethical research principles. All respondents in this study received an explanation of the study before 
completing and signing the consent form. The anonymity of respondents was protected, and this study met the ethical permit standards of the
Airlangga University Health Ethics and Research Commission (certificate number 1572-KEPK).

\section{RESULTS}

Table 1 The age distribution of the majority of students is 16 years old (39 respondents; $48.80 \%$ ), the majority sex is female (50 respondents; $62.50 \%$ ), the majority of parents are self-employed (58 respondents; $72.50 \%$ ), socioeconomic majority earns> Rp. 2,500,000 (62 respondents; 77.50\%)

\begin{tabular}{cccccc}
\hline Karakteristik & Indicator & Frequency & $\%$ & Mean & SD \\
\hline Age (years) & 15 & 25 & 31.2 & 1.90 & 0.739 \\
& 16 & 39 & 48.8 & & \\
\multirow{5}{*}{ Gender } & 17 & 15 & 18.8 & & \\
& 18 & 1 & 1.2 & & \\
Occupation parents & Male & 30 & 37.5 & 1.38 & 0.487 \\
& Female & 50 & 62.5 & & \\
& Farmers & 9 & 11.2 & 2.05 & 0.525 \\
Income/month & Entrepreneurs & 58 & 72.5 & & \\
& Civil servants & 13 & 16.2 & & \\
& Rp.500.000- Rp. 1.500 .000 & 2 & 2.5 & 2.75 & 0.490 \\
& Rp.1.500.000-Rp.2.500.000 & 16 & 20 & & \\
& $>$ Rp.2.500.000 & 62 & 77.5 & & \\
& Verbal & 56 & 70 & 1.40 & 0.668 \\
& Mass media & 16 & 20 & & \\
\hline
\end{tabular}

Table 2 The distribution of the level of knowledge about bullying the majority is high (60 respondents; $75 \%$ ), the majority of bullying behavior is unusual (62 respondents; $77.5 \%$ ) and the type of bullying the majority performs through verbal (56 respondents; $70 \%$ ), the results of statistical analysis, using a ranking test Sperman Rank, shows that there is a relationship between knowledge and bullying behavior among peers in adolescents, with a value of $p=0,000(p<0.05)$.

\begin{tabular}{ccccccc}
\hline Characteristics & Indicator & Frequency & $\%$ & Mean & SD & p \\
\hline Knowledge & High & 60 & 75 & 2.70 & 0.560 & 0.000 \\
& Medium & 16 & 20 & & & \\
Bullying behavior & Low & 4 & 5 & & & \\
& Usually done & 18 & 22.5 & 1.22 & 0.420 & \\
& Unusual to do & 62 & 77.5 & & & \\
\hline
\end{tabular}

\section{DISCUSSION}

School is one of the means for character education for children to have a spirit of mutual respect, mutual support and not to attack each other and their peers (Aulia, 2016). The results showed the contribution of knowledge to the practice of bullying, but all students had bullying and the majority were vebals (70\%) who were used in committing terror to peers. Their identification can help in increasing relationships between friends to avoid violence in adolescents (Menesini and Salmivalli, 2017). Knowledge generated from social information will be organized through the process of paying attention, remembering and thinking (Baron and Byrne, 2005). The theory is the background of the results of the study, that social priming attitudes (experience gained at this time) in the form of new knowledge possessed an important role to the effect of imitation of behavior (Cook and Bird, 2011). And the results of these studies justify the results of this study that bullying behavior by students is generated from the process of organizing information obtained from what is known, both from reading literature and experiences during associating with peers. Some of the bullying behaviors include verbal terror (calling names, threatening), physical terror (hitting, kicking, damaging the victim's possession), and social terror (exclusion, hoaxes), 
to the latest forms of attacks through mass media or the internet (Disseminating \& Salmivalli, 2017).

But for victims of bullying, it is rather difficult to distinguish between friendship and terror. Although parents and teachers consider the interaction carried out as bullying (Mishna, Wiener and Pepler, 2008). Teenagers prefer the meaning of friendship and forgiveness to ensure the peace of heart rather than feel the physical and psychological effects of bullying (Barcaccia et al., 2018), because it is considered a form of friendship that is very satisfying (Woods, Done and Kalsi, 2009), so it becomes a moral dilemma for teachers between wanting to protect and blame themselves when not helping victims (Brüggemann et al., 2019). In addition, bullying carried out by early adolescents is nothing more than the effect of a period of moral release. The period of moral release allows adolescents not to feel guilty when committing crimes and to the individual trying to escape moral sanctions. (Sijtsema et al., 2014), thus requiring an explanation by educators (Hymel and Bonanno, 2014) and maximum involvement of parents in controlling bullying behavior (Travlos et al., 2018).

The knowledge possessed is in vain and will be covered by a period of moral release from the process of growth and development, and adolescents are more concerned with fulfilling the needs of growth and development rather than obeying the knowledge they have, so adolescents feel facilitated by destructive actions without feeling depressed (Moore, 2015). That is why the knowledge possessed cannot be used as a guide to stop bullying behavior in adolescents, even though it is rarely done. A strong understanding of the effects of bullying needs to be given to adolescents. The results showed an increase in knowledge of bullying behavior after training with pedagogical creative approaches to students (Saibon, Leong and Har, 2017). Thus the hope aimed at adolescents to get through the period of growth and development without hurting peers. This study uses a small sample of 80 respondents, There several limitations in this study. Results can be confused by periods of moral release experienced by adolescents with behavior that feels innocent about their behavior.

\section{CONCLUSION}

In short, the findings of this study indicate that knowledge has positive implications for controlling bullying behavior for adolescents, although bullying behavior is always done by adolescents, nothing but to maintain friendship. The results of this study have clinical practice implications for preparing adolescents for growth and development (moral release) in order to control aggressive behavior with peers and others when more information is obtained about bullying behavior.

\section{REFERENCES}

Al-Raqqad, H. K. et al. (2017) 'The Impact of School Bullying On Students' Academic Achievement from Teachers Point of View', International Education Studies, 10(6), p. 44. doi: 10.5539/ies.v10n6p44.

AlBuhairan, F. et al. (2017) 'The relationship of bullying and physical violence to mental health and academic performance: A cross-sectional study among adolescents in Kingdom of Saudi Arabia', International Journal of Pediatrics and Adolescent Medicine. Elsevier Ltd, 4(2), pp. 61-65. doi: 10.1016/j.jpam.2016.12.005.

Aulia, F. (2016) 'Bullying experience in primary school children', SCHOULID: Indonesian Journal of School Counseling, 1(1), p. 28. doi: 10.23916/schoulid.v1i1.37.28-32.

Baldry, A. C. (2004) 'The impact of direct and indirect bullying on the mental and physical health of Italian youngsters', Aggressive Behavior, 30(5), pp. 343-355. doi: 10.1002/ab.20043.

Barcaccia, B. et al. (2018) 'Forgiveness and friendship protect adolescent victims of bullying from emotional maladjustment', Psicothema, 30(4), pp. 427-433. doi: 10.7334/psicothema2018.11.

Baron, R. A. and Byrne, D. (2005) Psikologi Sosial. 10th edn. Erlangga.

Barzeva, S. A., Meeus, W. H. J. and Oldehinkel, A. J. (2019) 'Social Withdrawal in Adolescence and Early Adulthood: Measurement Issues, Normative Development, and Distinct Trajectories', Journal of Abnormal Child Psychology. Journal of Abnormal Child Psychology, 47(5), pp. 865-879. doi: 10.1007/s10802-018-0497-4.

Beilmann, M. (2017) 'Dropping out because of the others: bullying among the students of Estonian vocational schools', British Journal of Sociology of Education. Routledge, 38(8), pp. 1139-1151. doi: 10.1080/01425692.2016.1251302.

Bellmore, A. et al. (2017) 'The Trouble with Bullying in High School: Issues and Considerations in Its Conceptualization', Adolescent Research Review. Springer International Publishing, 2(1), pp. 11-22. doi: 10.1007/s40894-016-0039-7.

Bjorklund, D. F. and Pellegrini, A. D. (2002) The Origins of Human Nature: Evolutionary Developmental Psychology. Washington, DC, US: American Psychological 
Association.

doi:

http://dx.doi.org/10.1037/10425-000.

Brüggemann, A. J. et al. (2019) 'Bystander passivity in health care and school settings: Moral disengagement, moral distress, and opportunities for moral education', Journal of Moral Education. Routledge, 48(2), pp. 199-213. doi: 10.1080/03057240.2018.1471391.

Cook, J. and Bird, G. (2011) 'Social attitudes differentially modulate imitation in adolescents and adults', Experimental Brain Research, 211(3-4), pp. 601-612. doi: 10.1007/s00221-011-2584-4.

Craig, W. M., Pepler, D. and Atlas, R. (2000) 'Observations of Bullying in the Playground and in the Classroom', School Psychology International, 21(1), pp. 2236. doi: 10.1177/0143034300211002.

Darney, C., Howcroft, G. and Stroud, L. (2013) 'the Impact That Bullying At School Has on an Individual'S Self-Esteem During Young Adulthood', International Journal of Education and Research, 1(8), pp. 1-16. Available at: www.ijern.com.

Diaz Herraiz, E. and Gutierrez, R. (2017) 'The HealthRelated Quality of Life of Students Involved in School Bullying', International Journal of School and Cognitive Psychology, 04(03). doi: 10.4172/24699837.1000198.

Fanti, K. A. and Henrich, C. C. (2015) 'Effects of SelfEsteem and Narcissism on Bullying and Victimization During Early Adolescence', Journal of Early Adolescence, 35(1), pp. 529. doi: $10.1177 / 0272431613519498$.

Fisher, K., Cassidy, B. and Mitchell, A. M. (2017) 'Bullying: Effects on School-Aged Children, Screening Tools, and Referral Sources', Journal of Community Health Nursing. Taylor \& Francis, 34(4), pp. 171179. doi: 10.1080/07370016.2017.1369801.

Fujikawa, S. et al. (2016) 'The association of current violence from adult family members with adolescent bullying involvement and suicidal feelings', PLoS ONE, 11(10), pp. 112. doi: 10.1371/journal.pone.0163707.

Fullchange, A. and Furlong, M. J. (2016) 'An Exploration of Effects of Bullying Victimization From a Complete Mental Health Perspective', SAGE Open, 6(1). doi: $10.1177 / 2158244015623593$.

Hinduja, S. and Patchin, J. W. (2019) 'Connecting Adolescent Suicide to the Severity of Bullying and Cyberbullying', Journal of School Violence. Routledge, 18(3), pp.
333-346.

doi:

10.1080/15388220.2018.1492417.

Hymel, S. and Bonanno, R. A. (2014) 'Moral Disengagement Processes in Bullying', Theory into Practice, 53(4), pp. 278-285. doi: 10.1080/00405841.2014.947219.

Itegi, F. M. (2017) 'Bullying and its Effects : Experiences in Kenyan Public Secondary Schools', 5(3), pp. 23-36.

Juvonen, J. and Graham, S. (2014) 'Bullying in Schools: The Power of Bullies and the Plight of Victims', Annual Review of Psychology, 65(1), pp. 159-185. doi: 10.1146/annurev-psych-010213-115030.

Le, H. T. H. et al. (2019) 'Mental health problems both precede and follow bullying among adolescents and the effects differ by gender: A cross-lagged panel analysis of school-based longitudinal data in Vietnam', International Journal of Mental Health Systems. BioMed Central, 13(1), pp. 1-10. doi: 10.1186/s13033-019-0291$x$.

Litwiller, B. J. and Brausch, A. M. (2013) 'Cyber Bullying and Physical Bullying in Adolescent Suicide: The Role of Violent Behavior and Substance Use', Journal of Youth and Adolescence, 42(5), pp. 675684. doi: 10.1007/s10964-013-9925-5.

Lopes Neto, A. A. (2005) 'Bullying - Aggressive behavior among students', Jornal de Pediatria, 81(5 SUPPL.), pp. 164-172. doi: 10.2223/JPED.1403.

Menesini, E. and Salmivalli, C. (2017) 'Bullying in schools: the state of knowledge and effective interventions', Psychology, Health and Medicine. Taylor \& Francis, 22, pp. 240-253. doi: 10.1080/13548506.2017.1279740.

Mishna, F., Wiener, J. and Pepler, D. (2008) 'Some of my best friends - Experiences of bullying within friendships', School Psychology International, 29(5), pp. 549573. doi: 10.1177/0143034308099201.

Moore, C. (2015) 'Moral disengagement', Current Opinion in Psychology. Elsevier Ltd, 6, pp. 199-204. doi: 10.1016/j.copsyc.2015.07.018.

Nasheeda, A., Hassan, N. C. and Hassan, S. A. (2016) 'Relationships between bullies, victims and mental health among adolescents in Maldives', The Maldives National Journal of Research, 5(1), pp. 23-44.

Oliveira, F. R. et al. (2018) 'Bullying effect on student's performance', EconomiA. National Association of Postgraduate Centers in Economics, ANPEC, 19(1), pp. 57-73. doi: 10.1016/j.econ.2017.10.001. 
Oriol, X., Miranda, R. and Amutio, A. (2019) 'Correlates of Bullying Victimization and Sexual Harassment: Implications for Life Satisfaction in Late Adolescents', The Journal of School Nursing, p. $105984051986384 . \quad$ doi: $10.1177 / 1059840519863845$.

Rivers, I. et al. (2009) 'Observing Bullying at School: The Mental Health Implications of Witness Status', School Psychology Quarterly, 24(4), pp. 211-223. doi: $10.1037 / \mathrm{a} 0018164$.

Saibon, J., Leong, A. and Har, C. (2017) 'Enhancing Knowledge of Bullying Behavior Through Creative', Malaysian Journal of Learning and Instruction, (Special Issues), pp. 197219.

Serra-Negra, J. M. et al. (2015) 'Verbal school bullying and life satisfaction among Brazilian adolescents: Profiles of the aggressor and the victim', Comprehensive Psychiatry. Elsevier Inc., 57, pp. 132-139. doi: 10.1016/j.comppsych.2014.11.004.

Sigurdson, J. F. et al. (2015) 'The long-term effects of being bullied or a bully in adolescence on externalizing and internalizing mental health problems in adulthood', Child and Adolescent Psychiatry and Mental Health. BioMed Central, 9(1), pp. 1-13. doi: 10.1186/s13034-015-0075-2.

Sijtsema, J. J. et al. (2014) 'Friendship Selection and Influence in Bullying and Defending : Effects of Moral Disengagement', (October). doi: 10.1037/a0037145.

Smith, P. K. (2014) Understanding School Bullying: Its Nature \& Prevention Strategies. London: SAGE. doi: http://dx.doi.org/10.4135/978147390685 3.
Stein, J. A., Dukes, R. L. and Warren, J. I. (2007) 'Adolescent male bullies, victims, and bully-victims: A comparison of psychosocial and behavioral characteristics', Journal of Pediatric Psychology, 32(3), pp. 273-282. doi: 10.1093/jpepsy/jsl023.

Townsend, L. et al. (2008) 'The relationship between bullying behaviours and high school dropout in Cape Town, South Africa', South African Journal of Psychology, 38(1), pp. 21-32. doi: $10.1177 / 008124630803800102$.

Travlos, A. K. et al. (2018) 'The Effect of Moral Disengagement on Bullying: Testing the Moderating Role of Personal and Social Factors', Journal of Interpersonal Violence. doi: $10.1177 / 0886260518760012$.

UNESCO (2019) Behind the numbers: Ending school violence and bullying. France.

Waisglass, N. (2017) 'The Lasting Effects of Cyber Bullying on WellBeingfile:///C:/Users/mary pc/Desktop/notes/Issue-Paper-13--Cyberbullying-in-SA---Impact-andResponses.pdf'.

Van Werf, C. Der (2014) ‘Desempeño académico y ambiente escolar: Efecto de la intimidación', Desarrollo y Sociedad, (74), pp. 275-308. doi: 10.13043/DYS.74.6.

Woods, S., Done, J. and Kalsi, H. (2009) 'Peer victimisation and internalising difficulties: The moderating role of friendship quality', Journal of Adolescence, 32(2), pp. 293-308. doi: 10.1016/j.adolescence.2008.03.005.

Young, R., Miles, S. and Alhabash, S. (2018) 'Attacks by Anons: A Content Analysis of Aggressive Posts, Victim Responses, and Bystander Interventions on a Social Media Site', Social Media and Society, 4(1). doi: $10.1177 / 2056305118762444$. 